\title{
MONITORING AND EVALUATION OF THE LEVEL OF DEVELOPMENT OF THE EUROPEAN REGIONAL SECURITY COMPLEX
}

\author{
Olena Bulatova ${ }^{1}$, Oleksandr Osaulenko ${ }^{2}$, Olha Zakharova ${ }^{3}$
}

\begin{abstract}
Intensification of destabilizing processes in the world economy, increasing the impact of global challenges and the spread of uncertainty in the conditions of economic activity actualize scientific research to ensure a high level of economic security of countries and regions. This in turn requires a thorough systematic analysis and assessment of the level of security and the state of the security environment based on the development of appropriate methodological tools. Taking it into account, the presented research is aimed at developing a system for monitoring and assessing the level of security development of the countries of the European region, based on the tools of multidimensional assessment and construction of complex integrated indicators. The article is aimed to development of the system for monitoring and assessing the EU security level, which consists of comprehensive assessment of the formation of security development factors, construction of the security level integrated indexes, which allowes to classify the EU countries according to the security level, to identify the features and intensity of the influence of the different determinants on the security level formation, to establish the peculiarities of the EU countries distribution within the regional security space. The object of the study is the regional security complex of the EU, based on the monitoring system - 24 indicators, which are systematized by nature (economic, sociodemographic, environmental) and direction of impact (incentives, disincentives), which are assessed for the period 2010-2019. The results show a high assessment of the integrated level of security in countries such as Ireland, Sweden, Denmark, Austria, Cyprus, Finland, Slovakia, the Netherlands, Luxembourg and Germany; Ireland, the Czech Republic, Hungary, Lithuania, and Denmark have the highest security positions in terms of the economic component of the security level, Cyprus, Slovenia, Ireland, Luxembourg and Slovenia in terms of socio-demographic, and Sweden, Austria, Denmark, Finland and Portugal in terms of environmental security. The reduced impact of the economic security component factors, maintaining a moderate impact of the socio-demographic security component factors, the increasing influence of the environmental factors are determined. Statistical analysis of the distribution of the EU countries by security level in 2010-2019 confirmed the tendency to equalize the level of security development of the EU countries within the regional security complex, to reduce the level of variation of integrated assessments of security levels, to increase the share of countries with high levels. Building a matrix of positioning of the EU countries by the integrated level of security and the intensity of its dynamics allowed to divide the countries and zones of relative security and danger, and to determine that the most risky positions are in Italy, Bulgaria and Romania. The practical significance of the results of the study lies in the possibility of applying the proposed system of monitoring the level of security in the development and implementation of regional security strategy of the EU development, which will more effectively monitor changes, prevent risks and threats, prevent negative consequences.
\end{abstract}

Key words: economic security, regional security complex, EU region, integrated index of security development level, security indicator.

JEL Classification: F52, R11, C40

\footnotetext{
Corresponding author:

${ }^{1}$ Mariupol State University, Ukraine.

E-mail: olena_bulatova@yahoo.com

ORCID: https:-//orcid.org/0000-0001-7938-7874

${ }^{2}$ National Academy of Statistics, Accounting and Audit, Ukraine.

E-mail: O.Osaulenko@nasoa.edu.ua

ORCID: https://orcid.org/0000-0002-7100-7176

${ }^{3}$ Mariupol State University, Ukraine.

E-mail: o.zakharova@mdu.in.ua

ORCID: https://orcid.org/0000-0002-8718-0205
} 


\section{Introduction}

A special place in the study of modern problems of the international security environment belongs to the problems of formation of regional security complexes, the development of which is associated with the transformations taking place within these complexes and taking into account global changes in the world economy. Regional security systems are formed by countries whose national security systems are interconnected that they make it impossible to solve security problems separately (Buzan, 2003).

The formation of the European regional security complex is directly related to the development of political and economic integration processes in the region. However, a certain weakening of the European Union's position in the world economy requires the definition of appropriate strategic priorities for the development of the association, which would contribute to solving the problems of intra-regional asymmetry in the context of current problems of sustainable development. The Lisbon Development Agenda, the Europe 2020 strategy demonstrated the lack of focus on the internal market, the inconsistency of the declared goals and implemented programs of sustainable and inclusive growth (Renda, 2017), which resulted in the adoption of a new Global Strategy for the Foreign and Security Policy of the European Union.

The aim of the study is to develop a system for monitoring and comprehensive assessment of the level of security in the development of the EU countries, which will allow to obtain a comprehensive quantitative assessment of the level of security, to determine indicators that influence the formation of the level of security, to determine the patterns of formation and features of the distribution of the EU countries in terms of security indicators within the regional security environment.

Within the framework of the study, based on the generally accepted methodology of multidimensional assessment, the development and use of an integral index of the level of development security is proposed, the assessment of which from the point of view of the patterns of dynamics and distribution, structural features and structural changes will determine the specifics of the formation of regional security of the EU complex and take into account the specifics when developing strategic guidelines development.

Among the most common methods of assessing the level of regional economic security should be noted the following: observation of key macroeconomic indicators and comparing them with threshold values, which are accepted as values not lower than the world average; assessment of the country's economic growth rates by macroeconomic indicators and the dynamics of their change; methods of expert evaluation used to describe the quantitative and qualitative characteristics of the studied processes; methods of analysis and processing of scenarios; optimization methods; methods of multidimensional statistical analysis and others. Considering the lack of a generally accepted assessment methodology in most countries and in world practice, the unstable nature of the development of the global environment, as a result of constant shifts in trends not only in economic, but also in sociodemographic, political and legal, environmental and economic development of national economies, the development of methodological tools analysis of the state of security and quantitative measurement of its level with the ability to identify threats and risks is relevant.

\section{Literature review}

The development of new regional arrangements in the world after the Second World War (especially with the end of the Cold War) contributed to the emergence of new "regional orders", which are characterized by their own security mechanisms that meet regional needs (Lake, Morgan, 1997). The countries of the region establish security regimes and develop a security environment through appropriate interstate cooperation. In fact, a multi-regional system of international relations is being formed in the world economy, the basis of which is several regional orders (Hurrell, 2007), which differ in various levels of development (Buzan, Little, 2000). Polar forms of regional order, respectively, can be war zones and zones of sustainable peace (Solingen, 1998), the evolution of which covers several stages of development of the respective orders (USAID, 1997) - war (as the highest level of instability in the region), crisis (unstable regional order with a high probability of armed conflict), unstable peace (high level of tension between actors in international relations, mistrust between them), sustainable peace (predictability, common rules), permanent peace (high level of cooperation between countries, common goals), harmony - the highest level of regional order, characterized by solidarity, generally accepted values, norms, standards.

Regional orders, which differ in their identity, combine global and international processes (Katzenstein, 2005). However, the nature of modern international conflicts is significantly influenced by the development of globalization processes. On the one hand, this is due to the inability and inefficiency of state institutions to qualitatively address issues of social development. The border between global and local is within each country, which increases their influence. On the other hand, the development of global processes affects the development of new conflicts - the struggle for natural resources in the context of economic and environmental degradation is decisive in most modern conflicts. Most of the conflicts that take place in the modern world 
are related to the definition of identity (which in most cases is not directly related to the state) (Newman, 2004), as political motives and ideology take a back seat (Kaldor, 2001). Current practices in the development of regionalization processes in the world economy show that the deepening of integration cooperation between countries does not necessarily lead to appropriate solidarity between integrating countries. Accordingly, the exogenous nature of ensuring the security development of the region will only intensify. Finding the right balance between functionality and territory requires the coordination of efforts by a group of countries within a geographical region, which will increase the potential of the regional economy, its complementarity, and so on. Expanding the spheres of influence of regionalism, which goes beyond predominantly trade relations (as was the case with old regionalism), will promote the development of all countries that are equally affected by deepening globalization (new regionalism) and achieved through the following benefits (Hettne, 1998): achieving a sufficient size, which is based on the cooperation of states to solve common problems, which increases the scale of action; ensuring a viable economy based on a model of selfsufficient development; focus on achieving stability as the ability to counteract the shocks of the outside world; protection of structural positions and access to markets, effective combination of efforts to influence raw material prices; ensuring stability through the inclusion of security issues in regional projects implemented through joint efforts; more efficient resource management, including through the development of environmental cooperation. Considering regionalism an important component of shaping global security, Marshall M. compares it to the "prisoner's dilemma" of whether or not such a system will work with members of the larger community (Marshall, 1999). However, the opposition to the whole system will lead to significant changes in the system of global distribution and consumption. Understanding this will stimulate the development of regional security systems within the global.

Practical aspects of ensuring a high level of European regional security, the development of appropriate security strategies for the EU countries require a thorough analysis and assessment of security and the state of the regional security environment, which in turn necessitates improved methodological approaches to developing and implementing appropriate tools.

\section{Research methodology}

The study proposes an approach to quantitative assessment and monitoring of the level of development of the European regional security complex, based on the implementation of the following stages:

1. Systematization of indicators for assessing the level of safety and security environment, determining the nature of the impact of indicators in terms of signals to change the level of security development, identification of indicator type (incentive, disincentive), assessment of possible critical (regulatory, standard, threshold, etc.) values, comparison with which allows to detect changes in the security level.

2. Calculation of the integrated level of development security on the basis of construction of the corresponding complex indicator; substantiation of the method of standardization of safety level indicators and the form of their aggregation into the corresponding integrated indicator.

Based on the approaches to the construction of complex indicators adopted in the international practice of economic analysis (OECD, 2008), an integrated index of security development level is proposed, which means a comprehensive comparative, relative assessment of the stability and sustainability of the national economic system in a given environment.

Among the key issues of constructing this index (in addition to substantiating its structure, which took place at the previous stage) are several points: firstly, determining the method of standardization of parameters; secondly, the choice of the form of aggregation of indicators to the integrated assessment.

Taking into the account the fact that the object of assessment is the security of the regional association (the EU countries), as a method of rationing chosen method z-scores, which when reducing various indicators to a comparative form takes into account both its average level in the sample and the level of variation of indicators in the sample of countries. Standardized estimates are calculated by formulas (1) followed by rationing using the standard normal integral distribution function (2)

$$
\begin{aligned}
& Z_{j}=\frac{X_{j}-\mu}{\sigma} \text { (incentive), } \\
& Z_{j}=\frac{\mu-X_{j}}{\sigma} \text { (disincentive) }
\end{aligned}
$$

where $X_{j}$ is the actual value of $j$-indicator,

$\mu$ is the average of $j$-indicator (according to selection),

$\sigma$ is the average squared deviation of $j$-indicator (according to selection).

$$
Z_{j}^{n o r m}=\frac{1}{\sqrt{2 \pi}} e^{-\frac{z_{j}^{2}}{2}}
$$

As for the form of the integral index, the linear form of aggregation with equal weights of indicators (based on the arithmetic weighted average) (3) was used:) (3):

$$
I_{i}=\sum_{j=1}^{n} Z_{j}^{\text {norm } \propto j},
$$

where $I_{i}$ is the integrated security index for the development of the country $i$;

$Z_{j}^{\text {norm }}$ are the normalized $z$-scores of safety indicators $j$; $a_{j}$ is the weight ratio of $j$-security indicators. 
3. Evaluation of indicators for a certain period of retrospection, analysis of patterns of their change, calculation of integrated safety indices.

In the study, the calculation of safety indices was conducted for the last 10 years (2010-2019) according to a sample of the EU countries.

4. Assessment of patterns of distribution of countries according to the integrated level of security, ranking of countries, their systematization and classification relative to the security level.

5. Assessment of the system of relationships between security indicators, their groups and the integrated level of security, which will identify the most significant criteria for the formation of the security level of countries.

\section{The research results}

Based on previous studies by the authors (Bulatova et al., 2020; Bezzubchenko, etc., 2020) which determine the relationship between security and sustainable development, in assessing the level of economic security, it is objectively necessary to take into account not only economic criteria but also social and environmental indicators. With this in mind, a systematization of indicators for assessing the level of security of the EU countries is proposed, which is determined from the standpoint of the degree of significance and nature of the impact on overall economic dynamics, and combined into three groups: economic, socio-demographic and environmentaleconomic (Table 1).

The dynamics of these indicators by the EU countries as a whole on average for the period 2010-2019 are presented in Table 2 .
Analysis of the dynamics of security indicators shows that the level of GDP for the study period increased by $5.8 \%$, amounting to 2019 data 34,443 USD per capita, which is $1.1 \%$ less than in 2014 . The GDP per capita of the EU is more than 3 times higher than the world average (11,436 USD in 2019). Economic growth rates for 2000-2019 did not exceed $2.7 \%$ (2017), were characterized by negative values in 2012-2013, have a slowdown in growth after 2017, are lower than the world average GDP growth $(2.47 \%$ against $1.52 \%$ for the EU in 2019). The inflation rate in the EU is low at $1.63 \%$ in 2019 (not exceeding the maximum estimate of $3.3 \%$ in 2011 ), lower than the world average of $2.3 \%$. The unemployment rate in the EU is $6.7 \%$ in 2019 (which is $23.6 \%$ higher than the world average of $5.4 \%$ ), while it should be noted that the unemployment rate in the period 2010-2016 was higher than the critical value in $8 \%$.

Regarding foreign trade indicators, there is a slowdown in the growth rates of both exports and imports (2.7\% increase in exports in 2019 against $11 \%$ in $2010 ; 3.8 \%$ increase in imports in 2019 against $9.7 \%$ in 2010 ), while a comparison of these average global rates indicates a faster growth of EU foreign trade ( $81.5 \%$ in exports, 2.3 times in imports). Compared to 2010, trade conditions for the EU countries improved insignificantly in the periods 2015-2017, 2019. Trade indices of the trade balance indicate the preservation of an active foreign trade balance and effective trade cooperation for the EU countries. The share of exogeneous investment in GDP, which is $22 \%$ in 2019 , exceeds $15 \%$, but less than $25 \%$, which indicates the preservation of a stabilization regime, under which there is moderate economic growth with low or constant economic

Table 1

Indicators of the level of security development of the EU countries

\begin{tabular}{|c|c|c|c|c|}
\hline \multicolumn{2}{|l|}{ Indicator / designation } & The nature of the impact & Type* & Critical value ${ }^{* *}$ \\
\hline \multicolumn{5}{|c|}{ Economic components } \\
\hline $\begin{array}{l}\text { GDP per capita (current } \\
\text { USD) }\end{array}$ & $\mathrm{E}_{1}$ & $\begin{array}{l}\text { Indicator of the level of socio-economic development, the growth of } \\
\text { which indicates an increase in the level of economic potential of the } \\
\text { country, creating conditions for economic growth and competitiveness. }\end{array}$ & I & $\begin{array}{l}\text { Below the average } \\
\text { level for EU } \\
\text { countries. }\end{array}$ \\
\hline GDP growth (annual \%) & $\mathrm{E}_{2}$ & $\begin{array}{l}\text { Indicator of the level of socio-economic development, the growth of } \\
\text { which indicates an increase in the level of economic potential of the } \\
\text { country, creating conditions for economic growth and competitiveness. }\end{array}$ & I & $\begin{array}{l}<0 \text {, below the } \\
\text { average level for } \\
\text { EU countries }\end{array}$ \\
\hline $\begin{array}{l}\text { Inflation, consumer prices } \\
\text { (annual \%) }\end{array}$ & $\mathrm{E}_{3}$ & $\begin{array}{l}\text { Indicator of changes in consumer prices. Values at the level of 1-2\% (up } \\
\text { to 5\%) stimulate demand and economic development; at more than 5\% } \\
\text { - alarm, threat to security and resilience. }\end{array}$ & $\mathrm{D}$ & $>5 \%$ \\
\hline $\begin{array}{l}\text { Unemployment, total (\% of } \\
\text { total labor force) }\end{array}$ & $\mathrm{E}_{4}$ & $\begin{array}{l}\text { The indicator of the share of the unemployed population in the structure } \\
\text { of employment, the growth of which is associated with a decline } \\
\text { in production, indicates the imperfection of the labor market, the } \\
\text { deterioration of the quality of labor potential, increasing social tensions } \\
\text { in society. }\end{array}$ & $\mathrm{D}$ & $\begin{array}{l}>8-10 \% \text {, above the } \\
\text { EU average }\end{array}$ \\
\hline $\begin{array}{l}\text { Exports of goods and } \\
\text { services (annual \% growth) }\end{array}$ & $\mathrm{E}_{5}$ & \multirow{2}{*}{$\begin{array}{l}\text { An indicator of the level of foreign trade activity of the country, the } \\
\text { growth of which indicates an increase in the level of intensity of foreign } \\
\text { trade cooperation, increasing the level of competitiveness in world } \\
\text { markets. }\end{array}$} & \multirow[t]{2}{*}{ I } & \multirow{2}{*}{$\begin{array}{l}\text { below the average } \\
\text { level for EU } \\
\text { countries }\end{array}$} \\
\hline $\begin{array}{l}\text { Imports of goods and } \\
\text { services (annual \% growth) }\end{array}$ & $\mathrm{E}_{6}$ & & & \\
\hline
\end{tabular}


(End of Table 1)

\begin{tabular}{|c|c|c|c|c|}
\hline \multicolumn{2}{|l|}{ Indicator / designation } & The nature of the impact & Type $^{*}$ & Critical value ${ }^{* *}$ \\
\hline $\begin{array}{l}\text { Terms of trade index (index } \\
\text { Base 2010), \% }\end{array}$ & $\mathrm{E}_{7}$ & $\begin{array}{l}\text { The indicator of change in export prices relative to changes in import } \\
\text { prices, characterizes the change in terms of trade for the country. }\end{array}$ & I & $<100 \%$ \\
\hline Trade balance Index, \% & $\mathrm{E}_{8}$ & $\begin{array}{l}\text { Indicator of the effectiveness of foreign trade cooperation, characterizes } \\
\text { how much foreign exchange earnings from exports cover the cost of } \\
\text { imports. }\end{array}$ & I & $<100 \%$ \\
\hline $\begin{array}{l}\text { Gross capital formation (\% } \\
\text { of GDP) }\end{array}$ & $\mathrm{E}_{9}$ & $\begin{array}{l}\text { The indicator of the level of the investment component of economic } \\
\text { development determines the type of economic development of the } \\
\text { country in terms of domestic investment opportunities to ensure } \\
\text { economic growth. }\end{array}$ & I & $\begin{array}{l}<15 \% \text { (falling } \\
\text { economic } \\
\text { development, } \\
\text { eating habits, rising } \\
\text { poverty, etc.); }\end{array}$ \\
\hline $\begin{array}{l}\text { Foreign direct investment, } \\
\text { net inflows ( } \% \text { of GDP) }\end{array}$ & $\mathrm{E}_{10}$ & $\begin{array}{l}\text { An indicator of a country's ability to attract foreign capital in order to } \\
\text { intensify economic development, in particular on an innovative basis. }\end{array}$ & I & $\begin{array}{l}<0 \text {, below the } \mathrm{EU} \\
\text { average }\end{array}$ \\
\hline $\begin{array}{l}\text { High-technology exports (\% } \\
\text { of manufactured exports) }\end{array}$ & $\mathrm{E}_{11}$ & $\begin{array}{l}\text { Indicator of quality (manufacturability) of the country's foreign trade, } \\
\text { the country's ability to produce innovative products, the criteria of } \\
\text { innovative competitiveness. }\end{array}$ & I & $\begin{array}{l}<10-15 \% \text {, below } \\
\text { the EU average }\end{array}$ \\
\hline $\begin{array}{l}\text { Total reserves in months of } \\
\text { imports }\end{array}$ & $\mathrm{E}_{12}$ & $\begin{array}{l}\text { Indicator of support for international currency liquidity, ensuring the } \\
\text { financial security of the state. }\end{array}$ & I & $<3$ \\
\hline External Debt, \% of GDP & $\mathrm{E}_{13}$ & $\begin{array}{l}\text { An indicator of the level of external debt, the growth of which signals } \\
\text { an increase in the external debt burden and the deterioration of the } \\
\text { country's financial security. }\end{array}$ & $\mathrm{D}$ & $\begin{array}{l}>50-55 \% \text {, above } \\
\text { the EU average }\end{array}$ \\
\hline $\begin{array}{l}\text { Government deficit/surplus, } \\
\% \text { to GDP }\end{array}$ & $\mathrm{E}_{14}$ & $\begin{array}{l}\text { An indicator of the balance of public finances, a deviation from zero } \\
\text { indicates a deterioration in budget security. }\end{array}$ & $\mathrm{D}$ & $\begin{array}{l}\text { Above average for } \\
\text { EU countries (by } \\
\text { value module) }\end{array}$ \\
\hline \multicolumn{5}{|c|}{ Socio-demographic components } \\
\hline $\begin{array}{l}\text { Total population growth } \\
\text { rates, annual }\end{array}$ & $\mathrm{S}_{3}$ & $\begin{array}{l}\text { Indicator of the nature of demographic development of the country, } \\
\text { the negative values of which indicate the processes of depopulation, } \\
\text { positive - expanded demographic reproduction }\end{array}$ & I & $\begin{array}{l}<0 \text {, below the EU } \\
\text { average }\end{array}$ \\
\hline $\begin{array}{l}\text { Life expectancy at birth, total } \\
\text { (years) }\end{array}$ & $\mathrm{S}_{4}$ & $\begin{array}{l}\text { The indicator, the growth of which is evidence of improved quality of life } \\
\text { and improved well-being, on the other hand causes changes in the age } \\
\text { structure of the population, increasing median age, intensifies the aging } \\
\text { process. }\end{array}$ & I & $\begin{array}{l}\text { Below the EU } \\
\text { average }\end{array}$ \\
\hline $\begin{array}{l}\text { Population ages } 65 \\
\text { and above (\% of total } \\
\text { population) }\end{array}$ & $\mathrm{S}_{5}$ & Indicator of demographic aging of the nation. & $\mathrm{D}$ & $\begin{array}{l}>7 \% \text {, above the } \mathrm{EU} \\
\text { average }\end{array}$ \\
\hline $\begin{array}{l}\text { Age dependency ratio ( } \% \text { of } \\
\text { working-age population) }\end{array}$ & $\mathrm{S}_{6}$ & $\begin{array}{l}\text { An indicator of the demographic burden on the working population, the } \\
\text { growth of which is due to an increase in life expectancy, age structure } \\
\text { of the population, creates an additional burden on the social protection } \\
\text { system. }\end{array}$ & $\mathrm{D}$ & $\begin{array}{l}\text { Above average for } \\
\text { EU countries }\end{array}$ \\
\hline $\begin{array}{l}\text { International migrant stock } \\
\text { (\% of population) }\end{array}$ & $\mathrm{S}_{7}$ & $\begin{array}{l}\text { An indicator of the mechanical movement of the population, the } \\
\text { uncontrolled growth of which is a threat to economic security. }\end{array}$ & $\mathrm{D}$ & $\begin{array}{l}\text { Above average for } \\
\text { EU countries }\end{array}$ \\
\hline $\begin{array}{l}\text { GINI index (World Bank } \\
\text { estimate) }\end{array}$ & $\mathrm{S}_{3}$ & $\begin{array}{l}\text { An indicator of income inequality and the concentration of wealth in the } \\
\text { economy or society, the growth of value is a signal of increasing the level } \\
\text { of income differentiation, the deterioration of security. }\end{array}$ & $\mathrm{D}$ & $>40$ \\
\hline $\begin{array}{l}\text { Income decile } \\
\text { defferentiation rate }\end{array}$ & $\mathrm{S}_{4}$ & $\begin{array}{l}\text { Indicator of the level of socio-economic inequality, income ratio of } 10 \% \\
\text { of the richest and poorest population. }\end{array}$ & $\mathrm{D}$ & $\begin{array}{l}>10 \text {, above the EU } \\
\text { average }\end{array}$ \\
\hline \multicolumn{5}{|c|}{ Environmental components } \\
\hline $\begin{array}{l}\text { Energy intensity of GDP, kg } \\
\text { per } 1000 \text { euro }\end{array}$ & $\mathrm{N}_{1}$ & Indicator of the level of energy efficiency of the economy. & $\mathrm{D}$ & $\begin{array}{l}\text { Below the EU } \\
\text { average }\end{array}$ \\
\hline $\begin{array}{l}\text { Share of energy from } \\
\text { renewable sources (use) }\end{array}$ & $\mathrm{N}_{2}$ & $\begin{array}{l}\text { The indicator of the quality of the energy balance, the level of } \\
\text { environmental friendliness, the growth of the share of renewable energy } \\
\text { sources indicates the formation of a more rational structure of energy } \\
\text { consumption in the country. }\end{array}$ & I & $\begin{array}{l}\text { Above average for } \\
\text { EU countries }\end{array}$ \\
\hline $\begin{array}{l}\text { Air emissions intensities, } \\
\text { grams per euro value added }\end{array}$ & $\mathrm{N}_{3}$ & $\begin{array}{l}\text { Indicator of environmental intensity of the economy, changes in which } \\
\text { indicate the degree of greening of the economy, the introduction of clean } \\
\text { and environmentally friendly technologies and industrial processes. }\end{array}$ & $\mathrm{D}$ & $\begin{array}{l}\text { Below the EU } \\
\text { average }\end{array}$ \\
\hline
\end{tabular}

Source: compiled by the authors, ${ }^{*} I$ - incentive, $D$ - disincentive; ${ }^{* *}$ - change in relation to which in a certain direction signals danger 
Table 2

Dynamics of indicators of the level of security development of the EU for the period 2010-2019

\begin{tabular}{|c|c|c|c|c|c|c|c|c|c|c|}
\hline Indicator & 2010 & 2011 & 2012 & 2013 & 2014 & 2015 & 2016 & 2017 & 2018 & 2019 \\
\hline GDP per capita (current USD) & 32932 & 35716 & 33159 & 34564 & 35243 & 30474 & 31163 & 33030 & 35660 & 34843 \\
\hline GDP growth (annual \%) & 2.2 & 1.8 & -0.7 & -0.1 & 1.6 & 2.4 & 2.1 & 2.7 & 2.1 & 1.5 \\
\hline Inflation, consumer prices (annual \%) & 1.5 & 3.3 & 2.7 & 1.2 & 0.2 & -0.1 & 0.2 & 1.4 & 1.7 & 1.6 \\
\hline Unemployment, total (\% of total labor force) & 9.8 & 9.8 & 10.8 & 11.3 & 10.8 & 10.0 & 9.1 & 8.1 & 7.3 & 6.7 \\
\hline Exports of goods and services (\% growth) & 11.0 & 6.7 & 2.2 & 2.1 & 5.0 & 6.6 & 3.4 & 5.7 & 3.7 & 2.7 \\
\hline Imports of goods and services (\% growth) & 9.7 & 4.7 & -0.9 & 1.5 & 5.4 & 7.4 & 4.4 & 5.4 & 3.6 & 3.8 \\
\hline Terms of trade index, $\%$ & 100.0 & 97.7 & 96.8 & 97.8 & 98.7 & 100.3 & 101.6 & 100.2 & 99.2 & 100.1 \\
\hline Trade balance index, $\%$ & 104.1 & 104.0 & 106.9 & 108.5 & 109.0 & 110.3 & 110.4 & 109.8 & 109.1 & 108.4 \\
\hline Gross capital formation (\% of GDP) & 21.2 & 21.7 & 20.2 & 19.8 & 20.2 & 20.6 & 20.7 & 21.2 & 21.8 & 22.0 \\
\hline Foreign direct investment, net inflows (\% of GDP) & 3.7 & 5.6 & 3.9 & 3.8 & 2.7 & 5.7 & 5.1 & 2.9 & 0.5 & 1.4 \\
\hline $\begin{array}{l}\text { High-technology exports } \\
\text { (\% of manufactured exports) }\end{array}$ & 16.9 & 16.1 & 16.7 & 16.7 & 16.8 & 17.4 & 17.6 & 16.0 & 15.6 & 15.6 \\
\hline Total reserves in months of imports & 3.1 & 2.7 & 3.1 & 3.0 & 2.6 & 2.9 & 3.1 & 3.6 & 3.2 & 3.4 \\
\hline External debt, $\%$ of GDP & 114.8 & 119.7 & 121.0 & 124.0 & 125.9 & 131.7 & 127.4 & 118.9 & 113.0 & 109.4 \\
\hline Government deficit/surplus, \% to GDP & -6.4 & -4.6 & -4.3 & -3.3 & -2.9 & -2.4 & -1.7 & -1.1 & -0.7 & -0.8 \\
\hline Total population growth rates, annual & 0.3 & 0.3 & 0.2 & 0.2 & 0.2 & 0.2 & 0.2 & 0.2 & 0.2 & 0.2 \\
\hline Life expectancy at birth, total (years) & 79.6 & 80.1 & 80.2 & 80.5 & 80.9 & 80.6 & 80.9 & 80.9 & 81.0 & 81.0 \\
\hline Population ages 65 and above (\% of total population) & 17.7 & 17.9 & 18.2 & 18.6 & 18.9 & 19.2 & 19.6 & 19.9 & 20.2 & 20.5 \\
\hline Age dependency ratio (\% of working-age population) & 49.5 & 50.1 & 50.7 & 51.3 & 52.0 & 52.7 & 53.3 & 54.0 & 54.7 & 55.4 \\
\hline International migrant stock (\% of population) & 10.5 & 10.5 & 10.5 & 10.5 & 10.5 & 11.4 & 11.4 & 11.5 & 11.5 & 12.5 \\
\hline GINI index (World Bank estimate) & 31.2 & 31.3 & 31.7 & 32.1 & 31.8 & 31.8 & 31.5 & 31.3 & 31.3 & 31.3 \\
\hline Income decile differentiation rate & 8.7 & 8.8 & 9.2 & 9.5 & 9.4 & 9.5 & 9.2 & 9.0 & 9.0 & 9.0 \\
\hline Energy intensity of GDP, kg per 1000 euro & 141.8 & 134.7 & 133.9 & 131.9 & 124.9 & 123.7 & 122.0 & 120.9 & 117.8 & 117.8 \\
\hline Share of energy from renewable sources (use) & 13.2 & 13.4 & 14.7 & 15.4 & 16.2 & 16.7 & 17.0 & 17.5 & 18.0 & 18.0 \\
\hline Air emissions intensities, grams per euro value added & 348.6 & 332.4 & 320.4 & 308.9 & 290.4 & 276.3 & 271.5 & 266.4 & 252.6 & 252.6 \\
\hline
\end{tabular}

Note: compiled by the authors on the basis (World Bank, 2020, Unctadstat, 2020, Ceicdata, 2020, United Nation , 2019, Eurostat, 2020).

dynamics. The share of net inflow of foreign investment to GDP in 2019 is $1.4 \%$, which is more than the previous year, but significantly less than the maximum levels of $2011,2015,2016$, when the figure exceeded $5 \%$. The share of high-tech exports exceeds $15 \%$ (the average for the period $2010-2019$ is 16.5 ) but less than the average world share (20.8\% in 2018 ). The level of gold and foreign exchange reserves in the months of imports is 3.4 according to 2019, on average for the analyzed period exceeds the critical value. For the EU countries, as for most developed countries, is characterized by a high level of external debt burden, the share of external debt in GDP for the EU as a whole exceeds $100 \%$.

The dynamics of socio-demographic indicators indicate the presence of constant low rates $(0.2 \%$ per year) of population growth and life expectancy (81 years according to 2019 data). Compared to world indicators, the EU countries are characterized by a lag in the pace of demographic development (the world's population growth rate is $1.07 \%$ ) and a lead in terms of quality of life (world life rate is 72.6 years). Regarding the peculiarities of the age structure, the EU countries are characterized by accelerating the aging process, the share of the population over the age of 65 has a growing trend of $20.5 \%$, while the world average is
9.2\%. As a result, the coefficient of demographic load is also increasing, for the period 2010-2019 it increased by $12 \%$ to the level of $55.4 \%$, which almost coincides with the world average coefficient $(54.5 \%)$. The share of migrants in the population structure for the analyzed period is in the range of $10-12 \%$. Indicators of uneven socio-economic development and income distribution do not go beyond the critical values, in particular, the Gini coefficient does not exceed 32\%, the coefficient of decile income differentiation is 9 .

Environmental and economic indicators show a favorable direction of change, in particular on the one hand a decrease in energy intensity (by $17 \%$ to $117.8 \mathrm{~kg}$ / 1000 euros of GDP in 2019) and the level of carbon intensity (by $17.5 \%$ to $252.6 \mathrm{~g} /$ euro GDP in 2019), on the other hand, an increase in the share of renewable energy sources in consumption from $13.2 \%$ in 2010 to $18 \%$ in 2019, which is evidence of the growing level of greening of the EU economies.

Based on the assessment and monitoring of these security indicators, it is possible to determine the countries with the most and least optimal values of indicators, to determine the shares of the EU countries in the relative security zone (with indicator above average) and in the zone of increasing threats or risks (with indicator below average) (Table 3 ). 
Vol. 7, No. 1, 2021

Table 3

Assessment of the distribution of the EU countries by indicators of the level of security (2019)

\begin{tabular}{|c|c|c|c|c|}
\hline Indicator & Minimum & Maximum & $\begin{array}{c}\text { Share of EU } \\
\text { countries above the } \\
\text { EU average, } \%\end{array}$ & $\begin{array}{c}\text { Share of EU } \\
\text { countries below the } \\
\text { EU average, \% }\end{array}$ \\
\hline GDP per capita (current USD) & $\begin{array}{c}9738 \\
\text { Bulgaria }\end{array}$ & $\begin{array}{c}114705 \\
\text { Luxembourg }\end{array}$ & 37 & 63 \\
\hline GDP growth (annual \%) & $\begin{array}{c}-0.03 \\
\text { Portugal }\end{array}$ & $\begin{array}{l}5.5 \\
\text { Ireland }\end{array}$ & 74 & 26 \\
\hline Inflation, consumer prices (annual \%) & $\begin{array}{c}0.25 \\
\text { Cyprus }\end{array}$ & $\begin{array}{c}3.83 \\
\text { Romania }\end{array}$ & 48 & 52 \\
\hline Unemployment, total (\% of total labor force) & $\begin{array}{c}1.93 \\
\text { The Czech } \\
\text { Republic }\end{array}$ & $\begin{array}{c}17.24 \\
\text { Greece }\end{array}$ & 22 & 78 \\
\hline Exports of goods and services (\% growth) & $\begin{array}{c}0.84 \\
\text { Luxembourg } \\
\end{array}$ & $\begin{array}{c}11.06 \\
\text { Ireland }\end{array}$ & 48 & 52 \\
\hline Imports of goods and services (\% growth) & $\begin{array}{c}-0.39 \\
\text { Italy }\end{array}$ & $\begin{array}{l}35.61 \\
\text { Ireland }\end{array}$ & 26 & 74 \\
\hline Terms of trade index, $\%$ & $\begin{array}{c}87.8 \\
\text { Luxembourg }\end{array}$ & $\begin{array}{l}106.8 \\
\text { Malta }\end{array}$ & 44 & 56 \\
\hline Trade balance index, $\%$ & $\begin{array}{c}91.27 \\
\text { Romania }\end{array}$ & $\begin{array}{c}120.83 \\
\text { Luxembourg }\end{array}$ & 41 & 59 \\
\hline Gross capital formation (\% of GDP) & $\begin{array}{c}12.54 \\
\text { Greece }\end{array}$ & $\begin{array}{l}43.82 \\
\text { Ireland }\end{array}$ & 52 & 48 \\
\hline Foreign direct investment, net inflows (\% of GDP) & $\begin{array}{l}-20.39 \\
\text { Ireland }\end{array}$ & $\begin{array}{l}97.05 \\
\text { Cyprus }\end{array}$ & 74 & 26 \\
\hline $\begin{array}{l}\text { High-technology exports (\% of manufactured } \\
\text { exports) }\end{array}$ & $\begin{array}{c}6.69 \\
\text { Portugal }\end{array}$ & $\begin{array}{l}29.44 \\
\text { Malta }\end{array}$ & 37 & 63 \\
\hline Total reserves in months of imports & $\begin{array}{c}0.03 \\
\text { Luxembourg }\end{array}$ & $\begin{array}{c}9.1 \\
\text { The Czech } \\
\text { Republic }\end{array}$ & 26 & 74 \\
\hline External debt, \% of GDP & $\begin{array}{c}47.73 \\
\text { Romania }\end{array}$ & $\begin{array}{c}5633.23 \\
\text { Luxembourg }\end{array}$ & 67 & 33 \\
\hline Government deficit/surplus, \% to GDP & $\begin{array}{c}-4.3 \\
\text { Romania }\end{array}$ & $\begin{array}{c}3.7 \\
\text { Denmark }\end{array}$ & 70 & 30 \\
\hline Total population growth rates, annual & $\begin{array}{c}-1.5 \\
\text { Lithuania }\end{array}$ & $\begin{array}{c}1.88 \\
\text { Luxembourg }\end{array}$ & 52 & 48 \\
\hline Life expectancy at birth, total (years) & $\begin{array}{c}74.8 \\
\text { Latvia }\end{array}$ & $\begin{array}{c}83.4 \\
\text { Spain }\end{array}$ & 56 & 44 \\
\hline Population ages 65 and above ( $\%$ of total population) & $\begin{array}{c}14.05 \\
\text { Cyprus }\end{array}$ & $\begin{array}{c}23.01 \\
\text { Italy }\end{array}$ & 30 & 70 \\
\hline Age dependency ratio ( $\%$ of working-age population) & $\begin{array}{c}42.82 \\
\text { Luxembourg }\end{array}$ & $\begin{array}{c}61.8 \\
\text { France }\end{array}$ & 37 & 63 \\
\hline International migrant stock (\% of population) & $\begin{array}{c}1.7 \\
\text { Poland }\end{array}$ & $\begin{array}{c}47.4 \\
\text { Luxembourg }\end{array}$ & 52 & 48 \\
\hline GINI index (World Bank estimate) & $\begin{array}{c}24.2 \\
\text { Slovenia }\end{array}$ & $\begin{array}{c}40.4 \\
\text { Bulgaria }\end{array}$ & 48 & 52 \\
\hline Income decile differentiation rate & $\begin{array}{c}4.98 \\
\text { Slovenia }\end{array}$ & $\begin{array}{c}16.79 \\
\text { Bulgaria }\end{array}$ & 33 & 67 \\
\hline Energy intensity of GDP, kg per 1000 euro & $\begin{array}{c}53.19 \\
\text { Ireland }\end{array}$ & $\begin{array}{c}414.36 \\
\text { Bulgaria }\end{array}$ & 74 & 26 \\
\hline Share of energy from renewable sources (use) & $\begin{array}{c}7.4 \\
\text { Netherlands }\end{array}$ & $\begin{array}{c}54.6 \\
\text { Sweden }\end{array}$ & 48 & 52 \\
\hline Air emissions intensities, grams per euro value added & $\begin{array}{c}128.7 \\
\text { Sweden }\end{array}$ & $\begin{array}{c}978.1 \\
\text { Bulgaria }\end{array}$ & 67 & 33 \\
\hline
\end{tabular}

Source: based on authors' calculations 


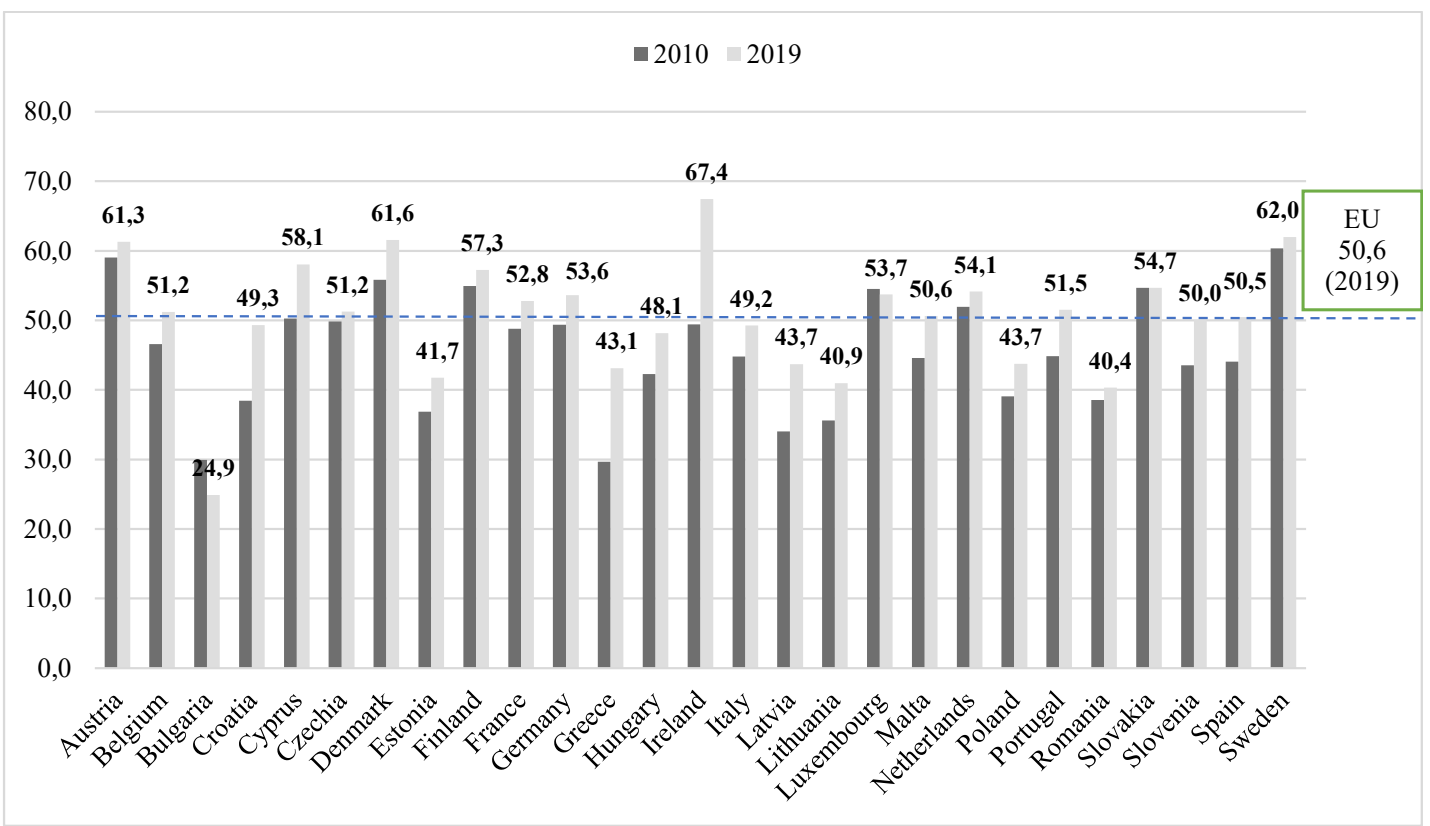

Figure 1. The EU countries according to the integrated level of security development $(2010,2019)$

Source: based on authors calculations

Table 4

Dynamics of integrated assessments (rating positions)

of the EU countries level of security development for the period 2010-2019

\begin{tabular}{|c|c|c|c|c|c|c|c|c|c|c|}
\hline EU country & 2010 & 2011 & 2012 & 2013 & 2014 & 2015 & 2016 & 2017 & 2018 & 2019 \\
\hline Austria & $59.0(2)$ & $58.7(3)$ & $60.8(3)$ & $58.4(3)$ & $57.1(3)$ & $56.7(4)$ & $56.9(4)$ & $58.1(23$ & $61.5(1)$ & $61.3(4)$ \\
\hline Belgium & $46.6(13)$ & $47.7(13)$ & $47.9(12)$ & $46.5(12)$ & $47.4(13)$ & $45.3(13)$ & $46.9(12)$ & $46.0(13)$ & $45.6(15)$ & \\
\hline Bulgaria & $.9(26)$ & $33.6(26)$ & $3.4(26)$ & $4.4(25)$ & & & $33.6(26)$ & & & \\
\hline Croatia & $3.4(22)$ & $40.3(20)$ & $37.4(25)$ & $41.0(20)$ & $40.6(21)$ & $42.5(17)$ & $44.5(18)$ & $42.4(20)$ & & \\
\hline Cyprus & $0.2(8)$ & $47.9(11)$ & $43.8(14)$ & $38.1(24)$ & $38.0(22)$ & $1.3(20)$ & $6.4(13)$ & $48.6(9)$ & & \\
\hline Czechia & $.0(1)$ & $50.5(9)$ & $48.7(11)$ & $46.2(13)$ & $49.1(10)$ & $46.6(12)$ & $46.4(14)$ & $47.7(11)$ & $48.8(9)$ & \\
\hline Denn & $5.8(3)$ & & $62.1(2)$ & $62.6(1)$ & $59.9(1)$ & $59.1(2)$ & $60.6(1)$ & $59.1(2)$ & & \\
\hline Estonia & $36.8(23)$ & $39.1(24)$ & $38.9(23)$ & $34.3(26)$ & 34.4 & 25) & 39.9 & (23) & $41.7(22)$ & \\
\hline Finland & $4.9(4)$ & $55.0(4)$ & $55.8(4)$ & & & & & & & \\
\hline France & $8.8(12)$ & & & & & & & & & \\
\hline Germany & $9.4(11)$ & $50.7(8)$ & & & & & & & & \\
\hline Greece & 7) & 30.0( & & & 33.9 & & 30.4 & & & \\
\hline Hungary & 9) & $45.4(15)$ & & & & & & & & \\
\hline Ireland & $.4(10)$ & $47.9(12)$ & $50.8(10)$ & & & & & & & \\
\hline Italy & $4.8(15)$ & $43.2(17)$ & & & & & & & & \\
\hline Latvia & $4.0(25)$ & $38.4(25)$ & & & & & & & & \\
\hline Lithuania & $.6(24)$ & 40.0( & & & & & & & & \\
\hline Luxembourg & $4.5(6)$ & & $54.6(5)$ & & & & $53.3(5)$ & & & \\
\hline Malta & $44.6(16)$ & $43.7(16)$ & $47.4(13)$ & $44.5(16)$ & $43.6(17)$ & $48.8(10)$ & $47.0(11)$ & $45.2(16)$ & $47.5(13)$ & $6(15)$ \\
\hline The Netherlands & $51.9(7)$ & $54.3(5)$ & $54.0(6)$ & $52.6(6)$ & $50.0(7)$ & $51.8(6)$ & $49.8(9)$ & $51.6(6)$ & $50.0(7)$ & $54.1(8)$ \\
\hline Poland & $39.1(20)$ & $39.2(23)$ & $40.1(21)$ & $39.9(22)$ & $40.8(20)$ & $40.9(21)$ & $42.6(22)$ & $42.3(21)$ & $43,8(18)$ & $43.7(21)$ \\
\hline Portugal & $44.8(14)$ & $42.3(18)$ & $40.1(20)$ & $45.8(14)$ & $44.5(16)$ & $42.2(19)$ & $43.9(21)$ & $46.6(12)$ & $47.5(14)$ & $51.5(12)$ \\
\hline Romania & $38.5(21)$ & $40.3(21)$ & $38.2(24)$ & $42.6(18)$ & $41.1(19)$ & $40.1(22)$ & $44.2(19)$ & $41.0(22)$ & $39.6(23)$ & $40.4(26)$ \\
\hline Slovakia & & & & & & & & & & $54.7(7)$ \\
\hline Slovenia & $43.5(18)$ & $45.7(14)$ & $41.8(16)$ & $43.2(17)$ & $44.8(15)$ & $44.2(15)$ & $45.4(15)$ & $45.9(15)$ & $45.6(16)$ & $50.0(17)$ \\
\hline Spain & & & & & & & & & & \\
\hline Sweden & $60.3(1)$ & $60.5(2)$ & $62.5(1)$ & $59.1(2)$ & $59.4(2)$ & $58.6(3)$ & $57.0(3)$ & $56.5(4)$ & $57.7(4)$ & $62.0(2)$ \\
\hline
\end{tabular}

Note: scores (rates) are mentioned in table.

Source: based on authors' calculations 
According to the data obtained, the distribution of the EU countries by security indicators such as economic growth, the share of domestic investment and net inflows of foreign investment in GDP, budget deficit, population growth, life expectancy and indicators of socio-economic inequality is the most favorable. points of higher specific weight of countries that have better indicators relative to the average level (higher or lower depending on the type of indicator).

The aggregation of security indicators on the basis of (1)-(3) allowed to calculate integrated assessments of the security level and, accordingly, to rank the EU countries on the state of the security environment (Figure 1, Table 4).

Ireland is in the top ten EU countries with the highest integrated estimates of the level of development security according to the results of the calculations (67.4; 1 position in 2019 relative to 10 places with an estimate of 49.4 in 2010, an increase of $36.5 \%$ ), Sweden $(62.0 ; 2$ nd position in 2019 relative to the 1st with an estimated 60.3 in 2010, an increase of $2.7 \%)$, Denmark (61.6; 3rd position in 2019). and 2010 with an estimate of 55.8 , an increase of $10.3 \%$ ), Austria $(61.3$; 4th po-sition in 2019 relative to the 2nd with an estimate of 59.0 in 2010, an increase of $3.8 \%$ ), Cyprus (58.1; 5th position in 2019 relative to the 8th with a score of 50.2 in 2010, an increase of $15.5 \%)$, Finland (57.3; 6th position in 2019 ) relative to the 4th with a score of 54.9 in 2010, an increase of $4.2 \%$ (Slovakia), Slovakia (54.7; 7th position in 2019 relative to the 5th with a score of 54.6 in 2010, growth of the level by $0.4 \%)$, the Netherlands $(54.1 ; 8$ position in 2019 relative to the 7th with a score of 51.9 in 2010 , growth of the level by $4.2 \%$ ), Luxembourg (53.7; 9th position in 2019 relative to the 6th with a score of 54.5 in 2010, a decrease of $1.5 \%$ ) and Germany (53.6); 10th position in 2019 relative to the 11th with a score of 49.4 in 2010, an increase of $8.6 \%$ ).

The EU countries with a higher security level than the EU average (50.6) include the Czech Republic, France, Malta and Portugal; the rest of the countries are characterized by an integrated level of security lower than the European average. The countries characterized by the most intensive growth rates of the integrated level for the period 2010-2019 include Croatia (28.2\%, 18 th position in 2019), Greece (45.3\%, 23 position), Latvia ( $28.4 \%, 22$ position). Among the EU countries, only Bulgaria shows a decrease in the integrated level (-17\%).

Considering the fact that in the structure of the integral assessment the indicators are classified into three groups - economic, socio-demographic and environmental-economic, the study calculated the corresponding sub-indices of the integral assessment of development security, on the basis of which the following were determined: the economic systems of such EU countries as Ireland, the Czech Republic, Hungary, Lithuania and Denmark are characterized; on socio-demographic indicators - Cyprus, Slovenia, Ireland, Luxembourg and Slovenia; on environmental and economic indicators - Sweden, Austria, Denmark, Finland and Portugal.

Assessment of the nature of the relationship between subcomponents and the overall integrated assessment (Figure 2) revealed the following patterns: firstly, the impact of purely economic indicators on the level of economic security has a declining trend, so if in 2010, there was a moderate correlation $(0,64)$, then in 2019 - weak (0.31); secondly, the impact of socio-demographic indicators remains virtually unchanged at the level of moderate correlation (0.67); thirdly, the intensity of the impact of environmental and economic indicators on the formation of the level of security is growing, so if in 2010 the correlation index was 0.58 (moderate correlation), in $2019-0.71$ (close). The results show the growing role of greening processes, the introduction of safer production technologies, the development of socially responsible business, ensuring sustainable economic growth and improving the welfare of the population.

The results of the assessment of the impact of certain indicators on the formation of the level of the EU countries security development showed: such indicators as energy efficiency and carbon intensity of GDP, population growth rates have a high correlation with the level of security; moderate correlation - the level of GDP per capita, gross capital formation in GDP, life expectancy, Gini index, the level of decile income differentiation; weak correlation, the level of inflation and unemployment, the index of conditions and trade and the state of the balance, the share of the population $65+$, the level of demographic burden, the share of FDI in GDP, the level of migration; other indicators, including GDP growth rates, exports and imports, the level of high-tech trade, financial indicators, have almost no impact on changes in the level of security.

In order to classify the EU countries on the level of security and the peculiarities of its formation and change, indicators of descriptive statistics (average and median values of indices, standard deviation, coefficient of variation) and some structural characteristics of the distribution (quartiles) were calculated (Table 5).

The structural characteristics of the distribution tend to increase, in particular: the average level increased by $11 \%$, the median value - by $14.3 \%$, the maximum value - by $11.8 \%$, the value of the first quartile - by $18.3 \%$, the third - by $6.5 \%$, which can be assessed as a positive moment in the formation of a higher level of security. According to the values, half of the EU countries are characterized by an integrated level of security not exceeding $50.6 \%, 25 \%$ of the 


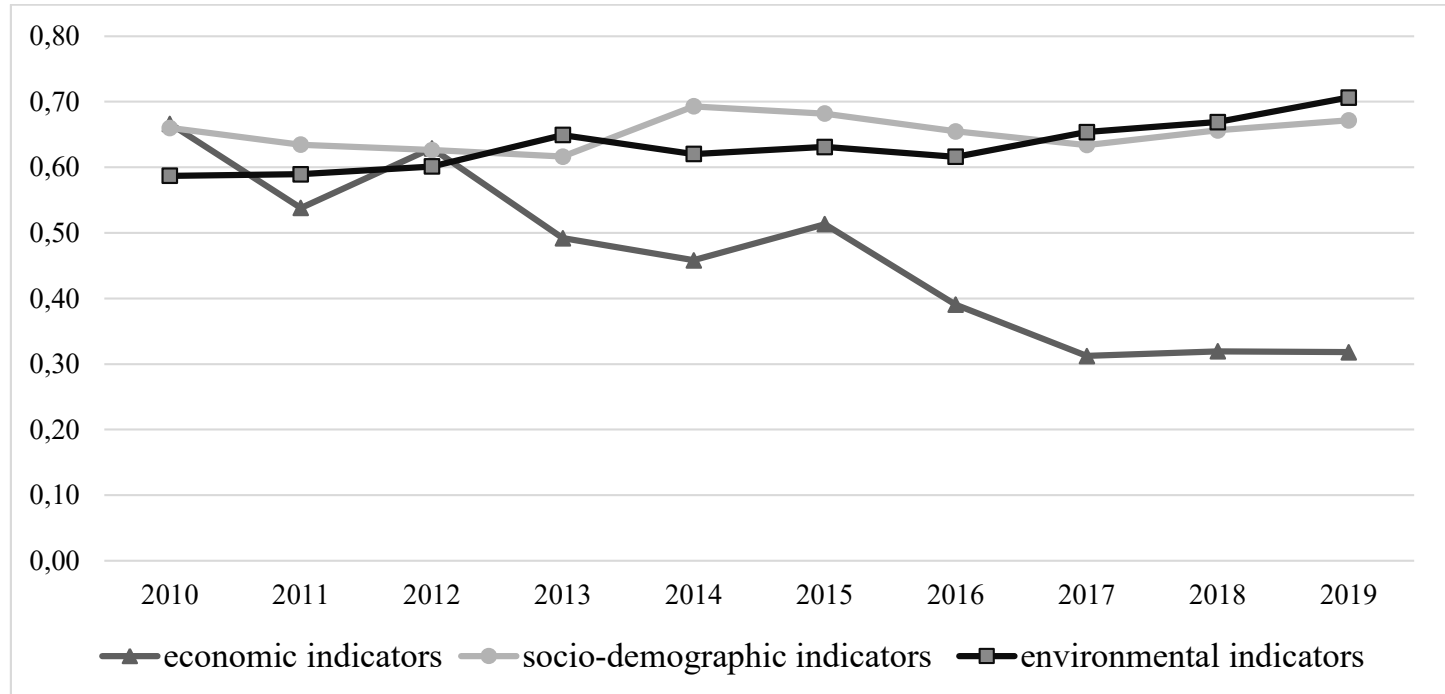

Figure 2. Correlation indices of the integrated level of the EU countries security development with the different subcomponents (indicators)

Source: based on authors calculations

Table 5

Statistical characteristics of the distribution of the EU countries by integrated level of security development (2010-2019)

\begin{tabular}{|l|c|c|c|c|c|c|c|c|c|c|}
\hline & 2010 & 2011 & 2012 & 2013 & 2014 & 2015 & 2016 & 2017 & 2018 & 2019 \\
\hline Mean & 45.6 & 46.4 & 46.2 & 46.2 & 45.7 & 45.6 & 46.4 & 46.2 & 46.8 & 50.6 \\
\hline Median & 44.8 & 45.7 & 43.8 & 45.8 & 45.2 & 44.6 & 46.4 & 45.9 & 47.5 & 51.2 \\
\hline First quartile & 38.8 & 40.3 & 40.1 & 40.9 & 40.7 & 41.1 & 44.0 & 42.3 & 42.8 & 45.9 \\
\hline Third quartile & 51.1 & 51.6 & 52.8 & 51.8 & 49.9 & 51.0 & 50.4 & 50.0 & 49.9 & 54.4 \\
\hline Min & 29.7 & 30.0 & 28.3 & 31.6 & 31.5 & 30.5 & 30.4 & 30.6 & 30.4 & 24.9 \\
\hline Max & 60.3 & 61.1 & 62.5 & 62.6 & 59.9 & 60.1 & 60.6 & 59.8 & 61.5 & 67.4 \\
\hline Standard deviation & 8.4 & 7.9 & 8.8 & 7.9 & 8.0 & 8.0 & 7.4 & 7.4 & 7.5 & 8.5 \\
\hline Variation rate & 18.5 & 17.0 & 19.1 & 17.1 & 17.6 & 17.5 & 16.0 & 15.9 & 16.1 & 16.9 \\
\hline
\end{tabular}

Source: based on authors' calculations

Table 6

Matrix of the EU countries by integrated safety index and the intensity of changes in its level

\begin{tabular}{|c|c|c|c|c|c|}
\hline \multirow{5}{*}{ 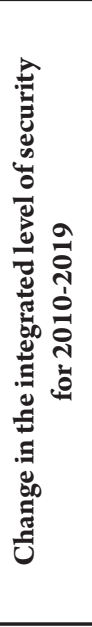 } & \multirow[b]{4}{*}{ 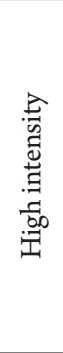 } & \multicolumn{4}{|c|}{ Integrated assessments of the level of security (2019) } \\
\hline & & \multicolumn{2}{|c|}{ Relative danger zone } & \multicolumn{2}{|c|}{ Relative safety zone } \\
\hline & & low & lower than the average & higher than the average & high \\
\hline & & $\begin{array}{c}\text { I } \\
\text { Estonia } \\
\text { Greece } \\
\text { Latvia } \\
\text { Lithuania } \\
\text { Poland }\end{array}$ & $\begin{array}{c}\text { II } \\
\text { Croatia } \\
\text { Hungary } \\
\text { Malta } \\
\text { Slovenia } \\
\text { Spain }\end{array}$ & $\begin{array}{c}\mathbf{V} \\
\text { Portugal }\end{array}$ & $\begin{array}{c}\text { VI } \\
\text { Ireland } \\
\text { Cyprus }\end{array}$ \\
\hline & 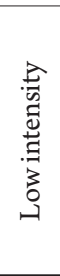 & $\begin{array}{c}\text { III } \\
\text { Bulgaria } \\
\text { Romania }\end{array}$ & $\begin{array}{c}\text { IV } \\
\text { Italy }\end{array}$ & $\begin{array}{c}\text { VII } \\
\text { Germany } \\
\text { Luxembourg } \\
\text { The Netherlands } \\
\text { Belgium } \\
\text { The Czech Republic } \\
\text { France }\end{array}$ & $\begin{array}{c}\text { VIII } \\
\text { Sweden } \\
\text { Austria } \\
\text { Denmark } \\
\text { Finland } \\
\text { Slovakia }\end{array}$ \\
\hline
\end{tabular}

Note: the division into groups according to the level of intensity of changes was carried out relative to the change of indices on average in the $\mathrm{EU}(\mathrm{Tpr}=11 \%)$, the division into groups according to the level of integrated safety assessment - according to structural characteristics (first quartile, median, third quartile).

Source: based on authors calculations 
safest countries have a security level not exceeding $45.9,25 \%$ of the safest - a level above 54.4, i.e. the degree differentiation between countries according to the calculated integrated estimates is low and is characterized by a downward trend. The calculation of variation indicators also confirms the fact of equalization of the level of security for countries within the EU, low variation allows us to conclude about the homogeneous nature of the set of the EU countries in the formation of a sufficiently high level of economic security. Taking into account the values of structural characteristics allowed to build a matrix of the EU countries on the level of development security, the intensity of changes in the parameters of the security environment (Table 6).

The highest risk areas are countries of groups III and IV, which have relatively medium lower (Italy) and low scores (Bulgaria and Romania) and are characterized by a low rate of increase of the integrated level. Group I and II countries (with the exception of Spain, these are the countries of the last waves of the EU enlargement), despite estimates below the average level, show higher rates of index growth, which is evidence of a more favorable security environment. Intensified rates of level change create additional opportunities for countries of groups $\mathrm{V}$ and VI to maintain and ensure a high level of security within the European space. Countries VII and VIII belong to economies with a sufficiently high level of security of development, for some of them low but stable growth rates are associated with a general high level of socioeconomic development and the ability to respond to threats of both internal and external nature (Germany, Sweden, Luxembourg, the Netherlands, etc.).

\section{Conclusions}

An important condition for ensuring and maintaining a high level of security development and the formation of a favorable security environment is the creation of a security level monitoring system based on appropriate national and regional security strategies. The basis of such monitoring is the quantitative measurement of the level of safety, the most successful tool of which is the method of multidimensional analysis and calculation of integrated indicators.

The proposed approach to assessing and analyzing the level of development of the regional security complex, tested on the example of the EU countries, allowed, first, to systematize the assessment criteria according to their essential characteristics, nature and direction of impact on security, possible critical values, and identify certain patterns changes for the EU countries; secondly, to assess the EU countries on the integrated level of security, to rank and classify, to assess the intensity of changes in the level, to determine the peculiarities of the distribution of countries within the EU by security assessments.

The use of correlation analysis tools allowed to confirm the fact of reducing the intensity of the impact of purely economic factors on the overall level of security and increasing the importance of social and environmental economic indicators in the formation of a higher level of development security.

The results of the analysis can be used in practice to develop national security strategies in terms of improving the security monitoring system, which will take into account changes in indicators, prevent the risks caused by certain changes and prevent the negative consequences of their manifestation.

\section{References:}

Buzan, B. et al. (2003). Regions and powers: the structure of international security. Vol. 91. Cambridge University Press.

Buzan, B., \& Little, R. (2000). International Systems in World History:Remarking the Study of International Relations. Oxford: Oxford University Press, 476 p.

Ceicdata (2020). Available at: https://www.ceicdata.com/en/indicator/france/external-debt--of-nominal-gdp

Eurostat (2020). Available at: https://ec.europa.eu/eurostat/data/database

Global Strategy for the European Union's Foreign and Security Policy (2016). Available at: http://eeas.europa.eu/ archives/docs/top_stories/pdf/eugs_review_web.pdf

Hettne, B. (1999). Globalism and New Regionalism / Hettne Björn, Inotai András and Sunkel Osvaldo. New York: Macmillan, 308 p.

Hrybinenko, O., Bulatova, O., \& Zakharova, O. (2020). Evaluation of demographic component of countries' economic security. Business, Management and Education, vol. 18(2), pp. 307-330. doi: 10.3846/jbem.2020.12309

Hrybinenko, O., Bulatova, O., \& Zakharova, O. (2020). Financial indicators in the system of economic security of the world countries. 11th International Scientific Conference "Business and Management 2020" May 7-8, 2020, Vilnius, Lithuania, pp. 273-281. doi: 10.3846/bm.2020.672

Hurrell, A. (2007). On Global Order. Power, Values, And The Constitution Of International Society. Oxford: Oxford University Press, $366 \mathrm{p}$.

Kaldor, M. (2001). New and Old Wars: Organized Crime in a Global Era / M. Kaldor. Cambridge: Polity Press, $216 \mathrm{p}$.

Katzenstein, P. (2005). A world of regions: Asia and Europe in the American imperium. Ithaca, London: Cornell University Press, $320 \mathrm{p}$. 
Lake, D., \& Morgan, P. (1997). Regional orders: Building security in a new world. Edited by David A. Lake and Patrick M. Morgan. University Park: Pennsylvania State University Press, 406 p.

Marshall, M. G. (1999). Third World War: System, Process, and Conflict Dynamics. Boston: Rowmanrowman \& Littlefield Publishers, Inc., $222 \mathrm{p}$.

Newman, E. (2004). The "New Wars" Debate: A Historical Perspective is Needed. Security Dialogue, vol. 35(2), pp. $173-189$.

OECD (2008). Handbook on constructing composite indicators. Methodology and user guide. OECD. Available at: https://www.oecd.org/sdd/42495745.pdf

Osaulenko, O., Yatsenko, O., Reznikova, N., Rusak, D., \& Nitsenko, V. (2020). The Productive Capacity of Countries Through the Prism of Sustainable Development Goals: Challenges to International Economic Security and to Competitiveness. Financial and credit activity problems of theory and practice, vol. 2(33), pp. 492-499. doi: $10.18371 /$ fcaptp.v2i33.207214

Renda, A. (2017). How can Sustainable Development Goals be 'mainstreamed' in the EU's Better Regulation Agenda? CEPS Policy Insights, no. 2017 (12), 17 p.

Reznikova, N. (2016). Ecological imperatives for extension of globalization processes: problem of economic security. Investytsiyi: praktyka ta dosvid, vol. 21, pp. 23-26.

Reznikova, N., Ivashchenko, O., \& Rubtsova, M. (2020). Global problems as a subject of interdisciplinary studies in the focus of international economic security and sustainable development. Ekonomika ta derzhava, vol. 7 , pp. 24-31. doi: 10.32702/2306-6806.2020.7.24

Reznikova, N., Panchenko, V. \& Bulatova, O. (2018). The Policy of Economic Nationalism: from Origins to New Variations of Economic Patriotism. Baltic Journal of Economic Studies, vol. 4, no. 4, pp. 274-281. doi: 10.30525/2256-0742/2018-4-4-274-281

Solingen, E. (1998). Regional orders at century's dawn: global and domestic influences on grand strategy. Vol. 77. Princeton University Press, $352 \mathrm{p}$.

Unctadstat (2020). Data center. Available at: https://unctadstat.unctad.org/wds/ReportFolders/reportFolders. aspx?sCS_ChosenLang=en

United Nations (2019). Department of Economic and Social Affairs. Population Division. International Migrant Stock. Available at: https://www.un.org/en/development/desa/population/migration/data/estimates2/ estimates19.asp

USAID (1997). Preventing and Mitigating Violent Conflicts: An Abridged Practitioner's Guide. U.S. Agency for International Development. Available at: http://pdf.usaid.gov/pdf_docs/pnaca995.pdf

World Bank (2020). Open Data. Available at: https://data.worldbank.org/

Zakharova, O., Bezzubchenko, O., Mityushkina, K., \& Nikolenko, T. (2020). Assessment of countries' international investment activity in the context of ensuring economic security. Problems and Perspectives in Management, vol. 18(4), pp. 72-84. doi: 10.21511/ppm.18(4).2020.07 